[Magazín Dominical]

\title{
La inercia de lo establecido ${ }^{A}$
}

\section{Germán Colmenares}

A diferencia de los países anglosajones-protestantes, la tradición católica hispana de Latinoamérica reserva el discurso moral a un cuerpo especializado. Mucho de la tradición crítica anglosajona está enraizada en actitudes éticas y políticas. Por eso no es raro que el nivel crítico en Latinoamérica sea tan bajo. Prácticamente no compete al individuo el juicio moral, sino que este ha sido entregado de antemano a un cuerpo eclesial que, a su turno, lo convierte en un motivo de predicación en ocasiones rituales y lo ejerce dentro de moldes de generalidad abstracta que nunca llegan a tocar situaciones concretas. Esta peculiaridad se funda en estructuras culturales que reposan sobre una base dogmática. Aquí, la vida no tiene por qué estar informada por impulsos morales que atañen al individuo puesto que todo individuo está inscrito en un orden más vasto cuyo movimiento debe superar toda iniciativa individual. La recepción individual de doctrinas europeas tiende a conformarse a este patrón. Se recibe la teoría en bloque y a lo sumo se la esquematiza y se la empobrece, pero no es dable elaborar sobre ella. Sus elementos constitutivos básicos deben permanecer intactos y sin ninguna experiencia concreta para modificarlos. Esto no obedece enteramente a complejos de inferioridad intelectual o sumisión acrítica creada por la dependencia cultural. Constituye una actitud profunda que atribuye a la integridad de la doctrina su eficacia. La teoría se convierte en un ritual del que no puede omitirse nada sin que se pierda su efecto como exorcismo o como ceremonia mágica.

A Publicado de manera póstuma en el Magazín Dominical del periódico El Espectador, 19 de mayo de 1991, 2, acompañado de la pequeña nota siguiente: "A un año de su muerte, rescatamos este texto inédito del agudo historiador colombiano". Ignoramos de quién fue la buena iniciativa. La copia en máquina que hizo Germán Colmenares, única que conocemos, tiene tres páginas (papel carta) y no lleva ni título ni firma, pero el título puesto por el periódico es tomado con acierto de la frase final del texto. No conocemos la fecha de redacción, pero es claro que el contexto es el de la violencia de los años 1980, que tanto hizo reflexionar a Colmenares, pero que nunca "antropologizó", por así decir, en el sentido de que nunca la convirtió en una realidad sin historia, ni la remitió a unos perdidos orígenes en el tiempo que permitirían hablar de "violencia ancestral", o, lo que es lo mismo, nunca habló de una "cultura de la violencia" siempre igual a sí misma, cárcel perpetua para una especie sin salvación. De una manera breve y condensada, concreta y sin especulación, Colmenares se dirige a la violencia como representación, y muestra la limitación de su estudio puramente estadístico o simplemente descriptivo y fenomenológico, y subraya la manera como esos enfoques, necesarios pero insuficientes, pueden de manera indirecta llegar a alimentar la permanencia de un fenómeno que se va incorporando como lamentable pero natural. La crítica de la reducción de la violencia a un conteo de víctimas la había expresado Colmenares varias veces. Una de ellas en su reseña de un libro de James Henderson, en donde recordaba la necesidad de una interpretación del fenómeno, más allá de los hechos más visibles, aunque de ninguna manera rechazaba el estudio de la fenomenología del proceso. 
Los colombianos hemos padecido todas las formas de violencia durante más de cuarenta años. Todo estudio sobre la violencia escrito en el extranjero comienza por observar cómo la palabra violencia designa un estado de cosas más o menos permanente, no un acto pasajero que rompe con un orden establecido. La violencia, aquí, no es una acción que se agota en su ejercicio, sino un fluido que envuelve la vida y se convierte en una parte de ella. La violencia no se atribuye a la conducta, sino que posee una entidad propia. Sobre ella no parece posible un juicio sino a lo sumo la comprobación material de su existencia y la especulación sobre sus causas, como si se tratara de un fenómeno físico. La violencia no tiene así un significado, como no lo tiene una piedra o un árbol. Ella está inscrita como cualidades semejantes a las de la malaria, la tifoidea o las viruelas. Se habla de su erradicación, de la misma manera que la de la roya o la de alguna enfermedad endémica. La violencia no es solo material, una cosa, sino que tiene su origen, o debe tenerlo, en causas materiales. La insinuación de que un acto violento es un acto de la voluntad, que no tiene una causa sino un significado, debe parecer muy extraña en Colombia. ¿Cómo podría establecerse un programa gubernamental de erradicación de la violencia sobre esta noción tan extraña? Se puede, por ejemplo, combatir el narcotráfico quemando miles de hectáreas de marihuana o de coca, destruyendo laboratorios o incautando aviones, etc. Pero a nadie se le ocurriría que valga la pena reflexionar sobre la condición de quienes ejercen ese curioso tráfico, o la lógica y la tradición de sus operaciones. De la misma manera, la violencia no parece involucrar personas sino estructuras que todo lo envuelven. $\mathrm{Su}$ misma persistencia en el tiempo parece probar que Colombia, a diferencia de casi todos los países de Hispanoamérica, ha alojado la violencia de manera irrevocable, que por algún extraño mecanismo social la violencia es una condición de nuestra existencia. En el extremo de este curioso razonamiento, a algunos hasta parece preocuparles qué pasaría si no tuviéramos la violencia.

La violencia se ha convertido en Colombia en una especie de garantía de la existencia del ser colectivo. El anonimato que encubre la mayoría de los actos de violencia se toma como un signo de que deben provenir de alguna entraña profunda e insondable. La naturaleza mítica de la violencia está tan arraigada que cuando se rompe la reticencia de una persona joven a abordar el asunto, cualquier intimidación de que no debería haber violencia la vuelve irascible y al momento trata de explicar la necesidad causal de que haya violencia. En esencia su argumento parece ser el de que si no hubiera violencia todo su horizonte vital experimentaría un hundimiento en el vacío. No estoy implicando que los jóvenes en Colombia tengan una inclinación a la violencia. Simplemente que han nacido en ella, que ella es una porción importante de su experiencia cotidiana y que por lo menos sienten una profunda incredulidad de que sea posible extirparla. La violencia para los jóvenes no es algo externo, como para los adultos. No es algo contra lo que se pueda actuar puesto que toda la conciencia que 
tienen de ella estás envuelta en el ropaje de las convenciones idiomáticas que subrayan su materialidad.

¿Qué pasó el nueve de abril? ¿Qué pasó en el Palacio de Justicia? ¿Qué pasó en Tacueyó? Cualquiera puede enterarse de los detalles horripilantes de estos sucesos. Nuestros periodistas suelen ser exhaustivos, especialmente por la radio, cuando de detalles macabros se trata. Pero ¿qué significan estos hechos? La pregunta esencial se elude siempre. Estos hechos se van incorporando a la materialidad de la mitología de la violencia como sucesivas capas geológicas que la vuelven más sólida e indestructible. Tal vez lo más inquietante del fenómeno colombiano sea que su violencia no tiene historia. Ella está ahí, siempre presente, sin alteraciones perceptibles, en olas sucesivas que no se diferencian unas de otras y que irrumpen con la monotonía y la regularidad de las marejadas.

Nada más peligroso que exhibir una simple indignación moral contra la violencia. Con raras excepciones, las prédicas indignadas constituyen una incitación abierta a otras violencias. Pero el otro extremo consiste en acercarse a ella como a una cosa que va creciendo como una formación rocosa por la simple adherencia de miles de hechos repetidos e inevitables. Una inercia intelectual inveterada frente a la violencia ha terminado por despojarla de toda significación. Ello ha conducido a su tratamiento puramente pragmático de causas y efectos, de probabilidades y de riesgos calculados. La cuestión que se plantea no es de si hay necesidad de un nuevo pacto social que renueve la confianza en unas instituciones, sino de hasta qué punto instituciones sin prestigio alguno pueden coexistir con amenazas que se sitúan en límites imprecisos. Se juzga que para mantener las amenazas a cierta distancia debe reforzarse más bien la inercia de lo establecido. 